\title{
Gästredaktörernas förord
}

\author{
Skevt växande och skavande
}

BEGREPPET SKEV ÄR en skandinavisering av queer som, sedan det myntades tidigt 2000-tal, har blivit en variation i sin egen rätt. Det är en översättning, en hybrid och ett begrepp i vardande. Det har använts på olika sätt och under åren fått sina egna betydelser, möjligheter och begränsningar.

Skevbegreppet har sina rötter i queerteori och växer därifrån. Nya korsningar dyker upp och sticklingar tas. De flätar in sig i varandra och i andra teoretiska begrepp. Att växa sidledes, menar Kathryn Bond Stockton (2009), är något annat än att växa upp. Att växa upp antyder att det finns en slutpunkt, att växandet tar slut vid en viss längd eller ålder och att det är linjärt. Sidledesväxande är oregelbundet, dröjande, egensinnigt och oberäkneligt - kanske kan det beskrivas som just skevt? José Muñoz (2009/2019) menar att queer är det som befinner sig vid horisonten, som vi måste kisa för att se. Det innebär att begreppet är i rörelse och att dess innebörd växlar. Vi tänker på skev på ett liknande sätt. Att tänka med skev är att stå med tårna djupt nedgrävda i jorden där de queera rötterna växer, men kanske delvis med blicken riktad åt ett annat håll. Kanske hålls huvudet lite på sned. Kanske kisar vi, låter blicken vinda.

Med det här temanumret vill vi dels göra en inventering av hur skev används i forskningen idag, dels fortsätta utforskandet av hur begreppet kan förändras och utvecklas. Användningen av skev är inte sam- 
stämmig, vare sig historiskt eller i numret, vilket innebär att begreppet är levande och under diskussion (Davis 2008). För att analysera skev manlig sexualitet skriver Hélène Ohlsson om en I80o-talsskådespelare. Elisabeth Stubberud, Helga Eggebø och Norman Anderssen undersöker hbtq-personers livsberättelser i 20Io-talets Norge. Fanny Pérez Aronsson tar upp samkönad sexualitet hos pojkar i nordamerikansk latinolitteratur. Desireé Ljungcrantz diskuterar och ägnar sig åt skevt poetiskt akademiskt skrivande. Dominik Dziedzic skriver om den skeva gosseskildringen hos författaren Viktor Rydberg. Slutligen föreslår Maria Lönn en skev och dekolonial metod som sätter kroppen och det sinnliga i centrum.

I det här förordet kommer vi att teckna en översiktlig bild av hur skevbegreppet vecklat ut sig. Eftersom vi båda har använt termen är vi själva del av hur skev växt fram och brukats. Maria Margareta Österholm (2012) skrev sin avhandling om skeva flickor i svenskspråkig prosa I980-2005 och Hilda Jakobsson (2018) använde skev i sin avhandling om flickors uppväxt, kärlek och sexualitet i Agnes von Krusenstjernas tidiga romaner. Eftersom vi då och då kommer att resonera utifrån vår egen forskning kommer vi att tala som ett vi men också om oss själva i tredje person. Vi vill fokusera det vi ser som möjliga teoretiska och metodologiska användningsområden, diskutera skevbegreppets relation till andra besläktade teoretiska begrepp och, givetvis, presentera artiklarna i det här numret och skapa kunskap om skev tillsammans med dem. Vi avslutar förordet med att föreslå skavsåret som figuration, ett sätt att sammanfatta och förkroppsliga skevbegreppet. Vi vill ge vår bild av det skeva växandet och också bidra till det, i ett fortgående samtal om vad skev kan innebära.

\section{Med rötterna i queer}

Skevbegreppets genealogi har skrivits några gånger (t.ex. Heggestad, Karlsson \& Williams 2005; Franck 2009; Österholm 2012; Jakobsson 2018, 2020) och en kort genomgång av dess historia finns även i några av artiklarna i detta nummer. Ordet skev talar i de skandinaviska språken om något som är snett, vint och krokigt och i förlängd betydelse udda. 
Skev har historiskt använts som slang för hbtq-personer (Borgström 2016, I24-25; Jakobsson 2020, I50). Det kan associeras med andra liknande uttryck för hbtq-personer från tidigt I9oo-tal, till exempel "såna" (Nilsson 1998; Österholm 2012, 54).

När queer slog igenom i Norden översattes det på sina håll till det inhemska språket för att ge liknande konnotationer som på originalspråk. I Norge översattes det till skeiv och användes främst för hbtqidentiteter i aktivistiska och kulturella sammanhang, medan queer användes för att tala om teori i akademiska sammanhang (Franck 2009, 25; Berg \& Wickman 2010, 90). Det är ett förhållningssätt som Stubberud, Eggebø och Anderssen delar i det här numret. Samma mönster finns i Danmark. I finskan har liknande försök att behålla queerbegreppets mening och associationer i ett nytt språkområde gjorts, men där har istället ordet pervo använts (Berg \& Wickman 2010, 90-9I).

I en svenskspråkig kontext ser skevbegreppets framväxt annorlunda ut. Liksom på många språk i världen översattes inte queer. Istället var det en grupp litteraturforskare som under tidigt 2000-tal valde att låna in norskans skeiv i form av det snarlika svenska skev. Det gjordes i ett specialnummer av Tidskrift för litteraturvetenskap (2005) vars tema var "skevt". Syftet var att pröva hur skev kan tillämpas i svenskspråkig litteraturforskning. Redaktörerna ville utvidga queerbegreppet och ta reda på om skev kan användas för att undersöka fler normativiteter och maktordningar. Inspirerade av den norska översättningen och den vardagliga betydelsen av ordet, menade de att skev innebär något som "sätter normaliteten i gungning, det som destabiliserar en ordning" (Heggestad, Karlsson \& Williams 2005, 3). I Tidskrift för litteraturvetenskap används skev på flera sätt, till exempel för brott mot flera olika normer, inte bara kopplade till kön och sexualitet (Sarrimo 2005; Munck 2005). Numret ger inga enhetliga svar på vad begreppet innebär eller hur det ska användas utan kan ses som påbörjandet av en begreppsutveckling.

Det blev startpunkten för förekomsten av skev som teoretiskt begrepp i svenskspråkig queerforskning, både i Sverige och Finland, inom humaniora och särskilt litteraturforskning. Mia Francks (2009) och Österholms (20I2) ovan nämnda avhandlingar i litteraturvetenskap har 
influerat bland andra Jakobsson (2018). Franck, Österholm och Jakobsson använder skev i analyser av skönlitterära ungdomsskildringar för ungdomar eller vuxna, främst om flickor som bryter mot heteronormativitet även om de är eller kan vara heterosexuella. Etnologen Michelle Göransson (2012) använder i sin avhandling begreppen att skeva, som innebär att avvika från normer, och att skava, för att beskriva den subjektiva upplevelsen av normbrott. I sin avhandling i nordisk folkloristik brukar Catarina Harjunen (2020) skevbegreppet för att förstå erotiska möten mellan människa och naturväsen i finlandssvenska folksägner. Även Mara Lee (2014) förhåller sig till skevbegreppet i sin avhandling i litterär gestaltning. Lee använder skev för att diskutera skrivande, läsande, kunskapsproduktion och tid i relation till ett flertal maktordningar och som ett sätt att visa vad det poetiska språket kan göra.

Hur begreppet skev ska användas på engelska är inte helt givet, vilket är en av orsakerna bakom valet att låta det här numret vara på skandinaviska språk. Skevbegreppet är skapat för att svara mot ett skandinaviskt sammanhang genom att ge vissa språkliga konnotationer, på samma sätt som queer gör i sin ursprungliga kontext. Det finns dock en poäng med att använda skev även inom andra språkområden på grund av de betydelser som termen fått i egen rätt. Jakobsson (2020, I52) har i en essä om skevbegreppet föreslagit två översättningar, även om såklart fler är möjliga: "skew" och "bent", som har sina respektive fördelar. När ett begrepp färdas, översätts och varieras behåller det en del av sin ursprungliga betydelse, men nya innebörder träder också fram. Skev är ju, som framgått, inte en direktöversättning av queer utan ett ord med andra betydelser och associationer. Att översätta begrepp och ta risken att förskjuta dem erbjuder nya möjligheter, menar vi.

\section{Att sätta ord på det undflyende}

Skevhet innebär sådant som rör sig utanför eller på gränsen till den heteronormativa ordningen, det problematiserar normer om kön och sexualitet men är inte begränsat till det (Classon Frangos \& Österholm 202I). Skev konnoterar det som är snett, vint och böjt på ett sätt som är svårt att definiera men som inger en gnagande känsla av att något inte 
står rätt till. Därför kan det användas för det som stör heteronormen och det binära genussystemet oavsett om det är homo- eller bisexuellt, trans eller heterosexuellt (Jakobsson 2020). I linje med det används begreppet i Ohlssons artikel "Skev sexualitet runt sekelskiftet igoo: Hur skådespelaren Gustaf Fredrikson blev homosexuell" för att beteckna sexualitet som ansågs normbrytande på ett sätt som inte kunde naglas fast samtidigt som homosexualitetsbegreppet växte fram. Skev kan fungera som ett komplement till queer och andra besläktade begrepp och teorier. Det som queer inte ser eller helt och fullt känns vid, det som skulle vara lite skevt att kalla queert i forskningen, kan skev sätta ord på.

Vi tänker oss att skev gror i mellanrummen mellan olika teoretiska begrepp, att det kan grävas fram och få växa på platser där queer eller till exempel crip (McRuer 2006) - ett annat begrepp som sidledes är släkt med queer - inte odlats. Skev skulle alltså inte ersätta övriga begrepp, men kunna spira där andra väderförhållanden råder. Det innebär att skev kan anslutas till teoretiska tankegångar men även användas för sig. Det kan komplettera och utöka analysen. När det är en enda röra i mellanrummen och stråna slingrar ihop sig, kan skev sätta ord på det som inte kan benämnas: det är något som skevar men vad? Skevheten är mindre intresserad av vilket blad och strå som tillhör vilken planta, var de börjar och slutar, och hänger sig åt trasslet mittemellan teoretiska begrepp och kategorier. Normaliteten gungar, vi vet inte alltid varför, men vi kan prova att kalla det skevhet och därmed förstå mer.

Skev kan användas för personer och företeelser som är heterosexuella även om de bryter mot normativiteten (cf. Franck 2009; Österholm 20I2; Jakobsson 20I8). Det kan till exempel handla om skev femininitet eller heterosexuella som skevar mot heteronormen, till exempel genom att "misslyckas" med att göra kön på förväntat sätt. Det har Österholm (2012, 2018) utforskat genom begreppet gurlesk - en aspekt av skev femininitet som blandar gullighet, grotesker och överdrifter. Det kan också vara fråga om att leva flersamt eller ägna sig åt icke-normativa sexuella handlingar (Classon Frangos \& Österholm 202I).

Det obestämbart skeva kan också erfaras i kroppens sensationer. När kroppar inte passar in utan hejdas, blir de medvetna om sina egna kon- 
turer. Skevheten sätter ord på den känsla som Sara Ahmed (2004, I48) illustrerar med sin fåtölj. Att sjunka ner i den är att känna sin kropps gränser och för vissa blir skavet mot huden, det som klämmer eller smärtar, extra tydligt. I "'Känn på det här' - om sinnlighet som en skev och dekolonial metod" beskriver Lönn skevs potential just som att överskrida fasta linjer mellan sexualitet, klass, ras, genus och ålder, där inget triumferar över det andra och där trasigheter existerar över gränserna.

Pérez Aronsson undersöker i sin artikel "'Chulito struggled to not cross the pato line' - representationer av skevt pojkskap i amerikansk latinolitteratur" hur latinopojkar blir skeva då de, till följd av flera samverkande maktordningar som sexualitet, språk, hudfärg och klass, inte uppfyller bilden av hur en latinopojke bör vara. Olika mellanpositioner skapar, enligt Pérez Aronsson, skeva subjekt. Pérez Aronsson beskriver det mellanförskap som karaktären Carlos hamnar i. Trots att Carlos skevande i hemorten associeras med vithet, hamnar han i ett mellanförskap i den vita universitetsvärlden där han markeras som avvikande på grund av sin etnicitet. I artikeln "När begäret går överstyr: Den skeva gosseskildringen i ljuset av skräckromantiken i Viktor Rydbergs Singoalla" visar Dziedzic hur gossen Sorgbarn, på ett liknande sätt, blir skev just för att han överskrider binära oppositioner såsom barndom/vuxenhet, norr/söder, mörker/ljus och "hedendom"/kristendom. Detta gör honom till en skev gestalt som destabiliserar den binära ordningen och skapar en skräckeffekt. Dziedzic och Pérez Aronsson visar också att skev kan vara kopplat till något som är "för mycket", något som sprider sig ut från rabatten och tar över hela trädgården. När skevheten hos latinopojkarna i Pérez Aronssons artikel flödar över i andras ögon, och när Sorgbarn väcker en excess av begär hos sin biologiska far, är skevheten i spel.

\section{Skeva berättelser och livslinjer}

Skev har spatiala konnotationer. Därför kan det ge ytterligare dimensioner till idéer som redan finns i queerforskningen. Att till exempel tala om en skev berättelse ger associationer till ett narrativ som svajar likt ett korthus på väg att kollapsa. Jakobsson (2018, I73-78; 2020, I52) beskriver skeva berättelser som bryter mot läsarförväntningar genom att 
kännetecknas av frånvaro, tystnad och antiklimax. Jakobsson inspireras av Jack Halberstams (201 I, 2-3, 53-86) forskning om queert misslyckande, där Halberstam undersöker framställningar som genomsyras av "unmaking, undoing, unbecoming" och "not knowing", i vilka ingen utveckling sker på ett sätt som ifrågasätter heteronormativitet.

Sådana gestaltningar kan även innefatta det som Österholm (2012, 284-86) betecknar som skeva slut, som inte uppfyller förväntningar om subversivitet. Verk med just sådana slut undersöker litteratur- och queerforskaren Derritt Mason (202I). Mason skriver om USA:s första ungdomsromaner med explicit hbtq-tematik från 1960- och 70-talen, vilka sedan länge betraktats som daterade på grund av att de är negativa och fyllda av misär. Mason sätter negativiteten och misären - det skeva - $\mathrm{i}$ fokus och ser hur berättelserna bryter mot förväntningar på att hbtq-personers livslinjer, och de romaner som skildrar dem, ska sluta i en stabil, positiv identitet. Mason (202 I, I54) återkommer till Stocktons (2009) begrepp sidledes växande och kallar det vid ett tillfälle "skewed", utan att känna till skevteori. Det vittnar om de fördelar som det rumsliga i skevbegreppet besitter. Kanske kan de skeva berättelserna ses som narrativ som växt sidledes, åt oväntade håll. I Masons (202I, 42) fall sammanfaller vad vi vill kalla en skev berättelse med en skev livslinje både livslinjerna som hbtq-ungdomsböckerna skildrar och romanernas slut bryter mot förväntningar.

Skevs spatialitet fungerar alltså även väl för att diskutera queer temporalitetsteori och dess idéer om livslinjen, som benämnts på flera olika sätt (cf. Halberstam 2005; Ahmed 2006; Ambjörnsson \& Jönsson 2010). Dessa bilder handlar om hur livet följer olika linjer och hur kroppar förväntas rikta och orientera sig efter "the straight line". Jakobsson (2018) talar om just en skev livslinje för att diskutera den livslinje som inte är rak eller straight utan som är böjd, krokig och bryter mot normativiteten. Genom att använda skev med dess rumsliga konnotationer blir det möjligt att vidareutveckla hur en skev livslinje, till skillnad från en rak, kan te sig (Jakobsson 2020, I52). Det ligger nära Stocktons (2009) resonemang om att växa sidledes och har samma spatiala dimension. Begreppet är också en bra utgångspunkt för att få syn på den raka livs- 
linjen som den skeva livslinjen skevar gentemot (Jakobsson 2020, I52).

I artikeln "Skeive liv: Felles fortellinger på tvers av forskjeller" undersöker Stubberud, Eggebø och Anderssen skeva personers livsberättelser och får syn på hur skevas livslinjer ter sig. De använder skev som beteckning på hela gruppen hbtq-personer istället för att särskilja mellan till exempel homosexuella, bisexuella och transpersoner, vilket gör det möjligt att se likheter inom gruppen. Artikeln kommer fram till att det, trots de många olikheterna, finns sex gemensamma teman: att känna sig annorlunda, negativa möten, att utforska sin identitet i relation till kön och sexualitet, att komma ut som skev, att komma in i skeva gemenskaper, och slutligen reflektion kring släktskap och familj. Dessa teman blir en del av berättelsen om livet som skev.

I relation till den skeva livslinjen skriver Jakobsson (2018) om skevt åldrande, som bryter mot normer om hur en livslinje ska se ut. En del av det åldrande Jakobsson beskriver är skevt kvinnoblivande, det vill säga att inte vilja eller kunna bli kvinna på förväntat sätt. I vissa av Krusenstjernas tidiga romaner, som står i fokus, upprepas kvinnoblivandet och når aldrig en slutpunkt. Detta bryter mot en förväntad livslinje. Jakobsson skriver specifikt om flickors uppväxt och skev har blivit viktigt för flickforskningen till följd av att skevforskare varit aktiva inom fältet (cf. Franck 2009; Österholm 20I 2). Den forskningen bygger Pérez Aronsson och Dziedzic vidare på i detta nummer, genom att istället fokusera på unga pojkars ålder och uppväxt. I sin artikel om den skeva gosseskildringen i Rydbergs roman Singoalla undersöker Dziedzic bland annat hur pojken Sorgbarns ålder är skev. Sorgbarn överskrider motsatsförhållandet mellan barn och vuxen, vilket skapar ett osammanhängande åldersuttryck. Det ser Dziedzic som en del av Sorgbarns skeva mellanposition och monstruositet. Men Dziedzic kopplar också Sorgbarns ålder till det faktum att gossen tillhör en "hednisk" folkgrupp som i romanen gestaltas som mer ursprunglig än kristendomen. Att den nioåriga pojken Sorgbarn representerar en "ursprungligare” grupp än den hans kristna far tillhör, vänder rollerna far och son upp och ner. Vem är egentligen den äldre, frågar sig Dziedzic. 


\section{Skeva läsningar och metoder}

Queer kan utgöra en metodologisk grund, vilken tar sig uttryck i begrepp som queera läsningar och läckage (Björklund 20I8). Detsamma gäller för skev, som kan användas som en analytisk term såväl som ett specifikt sätt att läsa och tolka (Franck 2009, 25-26; Österholm 20I2, 9I). Den skeva läsningen liknar vad nyss nämnda Mason (202I) gör med de skeva sluten. Att använda skev som metod kan handla om att avvika från de gängse forskningsmetoderna eller kombinera dem på oväntade vis, till exempel genom att låta känslor och sinnen ta plats och bli en del av metoden. Känslor av skevhet och hur skevhet känns blir utgångspunkter för undersökandet. Att läsa skevt kan även innebära att inta en lyssnande hållning för att ta reda på hur skevhet skildras och förhålla sig till hur det känns att vara ur spår (Sedgwick 2003; Classon Frangos \& Österholm 2021; Österholm 2012).

Ett skevt sätt att läsa tas upp i Tidskrift för litteraturvetenskap och förklaras som att söka det som oroar och stör. "Analysen sker, kan man kanske säga, på skrå" (Heggestad, Karlsson \&Williams 2005, 3). Dessa tankar har inspirerat Ohlssons artikel, som använder skev som ett sätt att diskutera avvikelser från köns- och sexualitetsnormer i en historisk kontext där ordet homosexualitet ännu inte tillämpades. För att närma sig sitt material, som består av bland annat brev och skämtteckningar, söker Ohlsson det som oroar och stör - även det som omgärdas av tystnad och överstrykningar. Hon läser orden eller meningarna som smått förskjutna och frågar sig vad som finns bakom dem, vad som händer i glappen. Den skeva läsart som Ohlsson beskriver är förankrad i kunskap om den historiska kontexten, men kan även brukas för att förstå andra tidsperioder eller sammanhang.

Om dekolonialitet innebär att omlära den västerländska traditionens sätt att skapa kunskap på, kan skev vara ett medel för olydnad mot denna tradition och kunskapspraktik, menar Lönn i sin artikel. Lönn vänder sig bort från synens privilegierade ställning i kunskapandet och utgår från det sinnliga i form av doft, smak och en kroppsnära blick. Förutom att visa hur skev kan komplettera och fördjupa andra teoretiska begrepp, bidrar Lönn till att utveckla skev som metod - ett sätt att 
utföra epistemisk olydnad, ett slags vetenskapligt hyss för att förstå världen på andra sätt. Det Lönn gör kan kopplas till hur Mara Lee (2014) betonar kroppens och erfarenhetens betydelse för läsande, skrivande och lärande. Lee menar att talet om rötter antyder att de är knutna till kroppen på ett linjärt sätt och därför kan väcka obehag hos de vars rötter är "avhuggna, skeva, rörliga och lagda i dunkel" (2014, I78). Även vi ansluter oss till talet om rötter, även om de i den här texten är queera och skeva. Ordet rot rimmar på hot och på franska "delar rot rot med rasism”, skriver Lee (20I4, I76). Med hjälp av det poetiska språkets associationer ser Lee ett frö till en skev rörelse bort från dessa förbindelser mellan ord och mot ett sätt att hitta andra kopplingar. Denna poetiska rörelse skulle kunna förstås som ytterligare ett sätt att växa sidledes med hjälp av skevbegreppet och som en konkret bild för hur vetenskaplig olydnad eller fantasi och rim kan vara ett sätt att skapa kunskap.

Det poetiska akademiska skrivandet kan ses som en skev metod i sig, men kanske lämpar det sig också för att vetenskapligt närma sig just det skeva? I Österholms (2012, 76) avhandling finns en ambition att skriva om "skeva flickor på skeviska" och alltså låta skevheten synas i den akademiska texten. Den skevhet som finns i de skönlitterära texterna får färga av sig på det akademiska språket och bidra till att lyfta fram en stilistisk skevhet. Det skeva akademiska skrivandet sker även i skapandet av figurationer - ett sätt att låta teori få kropp och röst - som använts av ett flertal genusforskare. Hos Österholm (20I2) är den skeva flickan den övergripande figurationen och varje kapitel handlar om olika aspekter av henne. Figurationen är inspirerad av och skapad utifrån de litterära texter som är avhandlingens ämne. Skönlitteraturens skeva språk och flickskap växer alltså ihop med det akademiska språket och skevteorin. Ljungcrantz utreder i "En skev figuration: Skrubbsåret som poetiskt akademiskt skrivande" skillnaden mellan kreativt och poetiskt akademiskt skrivande och utforskar och tillämpar i artikeln också ett poetiskt skrivsätt. Det poetiska akademiska skrivandet, menar Ljungcrantz, lägger sig närmare kroppar, känslor, erfarenheter och sinnlighet och kan på så vis begripliggöra komplexiteter och skevheter. Ljungcrantz menar att feministiska figurationer har en subversiv intention och vill föränd- 
ring. Hon ser figurationer som utforskande verktyg - ständigt i omdaning och välkomnande nya skeva perspektiv och kroppar - för att skapa kunskap om det vi ännu inte vet. Artikelns utgångspunkt är den egna figurationen skrubbsåret, som hon skapat $\mathrm{i}$ samband med sitt avhandlingsarbete om levda erfarenheter av hiv. Denna figuration, menar hon, kan även användas för att förstå andra "erfarenheter i form av trauman och kollisioner med samhällskroppen".

\section{Spretiga rötter i det obekväma, olydiga, trasiga och såriga}

I sidledesväxandets skeva anda vill vi, inspirerade av Ljungcrantz skrubbsår och Göranssons (2012) åtskillnad mellan skevande och skavande, åkalla skavsåret som figuration. Alla som haft ett skavsår vet att det kan innebära alltifrån begynnande små stick och vattniga blåsor till blod och en smärta som gör sig påmind i varje steg - ibland även när den obekväma skon byts ut eller tas av. Skev täcker in olika nivåer och intensiteter av plåga. Det ympar in sig på queerbegreppets historiska och nutida betydelser och blir till ett utskott på queerteorins livslinje. Med skavsåret som figuration vill vi samla in de teoretiska och metodologiska aspekter av begreppet skev som vi här har berört och som tar sig uttryck i de berättelser - ur såväl fiktion som levd erfarenhet - som är ämne för artiklarna i det här numret. Skavsåret innefattar upplevelsen av att vara eller uppfattas som skev, men också det att skava mot normaliteten och på så sätt tillfoga den ett sår. Skev skaver och genom skavsåret vill vi påminna om begreppets spretiga rötter i det obekväma, olydiga och trasiga som har sitt ursprung i orättvisor och ojämlikheter - om att skevhet gör ont.

\section{REFERENSER}

Ahmed, Sara. 2004. The Cultural Politics of Emotion. Edinburgh: Edinburgh University Press.

-. 2006. Queer Phenomenology: Orientations, Objects, Others. Durham: Duke University Press.

Ambjörnsson, Fanny \& Maria Jönsson. 20Io. ”Inledning." I Livslinjer: Berättelser om ålder, genus och sexualitet, redaktörer Fanny Ambjörnsson och Maria Jönsson, 7-2 I. Göteborg: Makadam. 
Berg, Martin \& Jan Wickman. 2oro. Queer. Malmö: Liber.

Björklund, Jenny. 20I8. "Queer Readings/Reading the Queer." lambda nordica 23.I-2: 7-I5.

Borgström, Eva. 2016. Berättelser om det förbjudna: Begär mellan kvinnor i svensk litteratur I900-I935. Göteborg: Makadam.

Davis, Kathy. 2008. "Intersectionality as a Buzzword. A Sociology of Science Perspective on what makes a Feminist Theory Successful”. Feminist Theory 9.r: 67-85.

Franck, Mia. 2009. Frigjord oskuld: Heterosexuellt mognadsimperativ i svensk ungdomsroman. Diss., Åbo Akademi.

Classon Frangos, Mike \& Maria Margareta Österholm. Kommande 202 I. ”När ska du ha barn? Skeva livslinjer i svenska feministiska serieböcker." Tidskrift för genusvetenskap 42.2-3: 6-24.

Göransson, Michelle. 201 2. Materialiserade sexualiteter: Om hur normer framträder, förhandlas och ges hållbarhet. Diss., Stockholms universitet. Göteborg: Makadam.

Halberstam, Jack. 20I r. The Queer Art of Failure. Durham: Duke University Press.

Harjunen, Catarina. 2020. Att dansa med de(t) skeva: Om erotiska möten mellan människa och naturväsen i finlandssvenska folksägner. Diss., Åbo Akademi.

Heggestad, Eva, Maria Karlsson \& Anna Williams. 2005. ”Inledning." Tidskrift för litteraturvetenskap 35.3:3-6.

Jakobsson, Hilda. 2018. Jag var kvinna: Flickor, kärlek och sexualitet i Agnes von Krusenstjernas tidiga romaner. Diss., Stockholms universitet. Göteborg: Makadam.

—. 2020. "Skev." lambda nordica. Tema: Queer Concepts for the 2020s. 25.I: 150-54.

Lee, Mara. 2014. När andra skriver: Skrivande som motstånd, ansvar och tid. Diss., Göteborgs universitet. Göteborg: Glänta produktion.

Mason, Derritt. 2021. Queer Anxieties of Young Adult Literature and Culture. Jackson: University Press of Mississippi.

McRuer, Robert. 2006. Crip Theory: Cultural Signs of Queerness and Disability. New York: New York University Press.

Munck, Kerstin. 2005. "Hon är svart och lesbisk': Om intersektionella röster i Nella Larsens romaner." Tidskrift för litteraturvetenskap 35-3: 7-19.

Muñoz, José Esteban. 2019 [2009]. Cruising Utopia: The Then and There of Queer Futurity. New York: New York University Press.

Nilsson, Arne. 1998. Såna och riktiga karlar: Om manlig homosexualitet i Göteborg decennierna kring andra världskriget. Göteborg: Anamma.

Sarrimo, Christine. 2005. "Risbastun i banken och mordet på Ahirab: Homoerotik och estetik i Heidenstams brev till Levertin." Tidskrift för litteraturvetenskap 35.3: 20-4I.

Sedgwick, Eve Kosofsky. 2002. Touching Feeling: Affect, Pedagogy, Performativity. Durham: Duke University Press.

Stockton, Kathryn Bond. 2009. The Queer Child, or Growing Sideways in the Twentieth Century. Durham: Duke University Press. 
Tidskrift för litteraturvetenskap. 2005. Tema: "Skevt." 35·3.

Österholm, Maria Margareta. 20I2. Ett ficklaboratorium i valda bitar: Skeva flickor $i$ svenskspråkig prosa från 1980 till 2005. Diss., Uppsala universitet. Årsta: Rosenlarv. —. 2018. "Rainbow Coloured Dots and Rebellious Old Ladies: The Gurlesque in Two Contemporary Swedish Comic Books." European Journal of Women's Studies: Femininity Revisited: Figuring Critical Femininity Studies 25.3: 37 I-83. 